\title{
TIPOLOGI, DINAMIKA, DAN POTENSI BENCANA ALAM DI KAWASAN PESISIR KABUPATEN TULUNGAGUNG
}

\author{
Anggoro Putranto ${ }^{1^{*}}$ \\ ${ }^{1}$ IAIN Tulungagung, Jl. Mayor Sujadi, No.46 \\ *e-mail: anggoro43@gmail.com
}

diterima:29 November 2019; direvisi: 20 Desember 2019; disetujui: 19 Januari 2020

\begin{abstract}
ABSTRAK
Penelitian ini bertujuan untuk mengetahui bentuk tipologi, dinamika dan potensi bencana alam di kawasan pesisir Kabupaten Tulungagung, Provinsi Jawa Timur. Hasil penelitian ini menunjukan bentuk tipologi yang ada di kawasan pesisir Kabupaten Tulungagung terdiri dari structurally shaped coast, wave erosion coast, marine deposition coast, land erosion coast, sub aerial deposition coast dan beberapa bentuk tipologi dampak dari kegiatan manusia memanfaatkan sumberdaya pesisir. Bentuk dinamika yang berkembang di kawasan pesisir Kabupaten Tulungagung secara umum dipengaruhi oleh faktor keadaan lingkungan, faktor gelombang air laut serta aktivitas manusia dalam memenuhi kebutuhan hidup maupun untuk pemenuhan sarana prasara perkembangan pariwisata. Sedangkan potensi bencana yang ada di kawasan pesisir Kabupaten Tulungagung seperti bencana tsunami, abrasi, intrusi air laut.
\end{abstract}

\section{Kata Kunci: Bencana pesisir, Dinamika Pesisir, Tipologi Pesisir, Tulungagung}

\section{TYPOLOGY, DYNAMICS, AND POTENTIAL OF NATURAL DISASTERS IN THE COASTAL AREAS OF TULUNGAGUNG REGENCY}

\begin{abstract}
This study aims to determine the typology, dynamics and potential of natural disasters in the coastal area of Tulungagung Regency, East Java Province. The results of this study indicate that the typology in the coastal area of Tuluagung Regency consists of structurally shaped coast, wave erosion coast, marine deposition coast, land erosion coast, sub aerial deposition coast and several forms of typology impact from human activities utilizing coastal resources. The form of dynamics that develop in the coastal area of Tulungagung Regency is generally influenced by environmental conditions, factors of sea water waves and human activities in meeting the needs of life as well as for meeting the means of tourism development. While the potential for disasters in the coastal areas of Tulungagung Regency such as tsunami, abrasion, and sea water intrusion.
\end{abstract}

Key words: coastal disaster, coastal dynamics, coastal typology, Tulungagung 


\section{PENDAHULUAN}

Indonesia merupakan salah satu negara yang wilayahnya merupakan kepulauan terbesar di dunia dengan memiliki lebih dari 17.508 pulau. Wilayahnya meliputi laut yang luasnya kurang lebih 500 juta hektar dan daratan kurang lebih 193 juta hektar dan tentunya memiliki kekayaan yang sangat besar sumber daya alam yang ada baik dari laut maupun yang ada di darat. Adapun jumlah binatang 400.000 dan lebih dari 25.000 jenis tumbuhan dan berbagai ekosistem dan biota yang belum teridentifikasi dapat hidup di iklim Indonesia, memberikan banyak kesempatan yang lebih bermanfaat pada masyarakat yang bertempat tinggal didalamnya (Departemen Kehutanan, 1992). Selain kaya sumberdaya pesisir dan pulaupulau kecil, wilayah pesisir juga dimanfaatkan masyarakat untuk bermukim. Dinamika perubahan di wilayah pesisir juga sangat dinamis, yang tidak hanya disebabkan oleh faktor alam saja melainkan karena berkembangnya pemanfaatan sumberdaya alam. Kegiatan yang tidak seimbang antara pemanfaatan dan pelestarian lingkungan pesisir dapat mengakibatkan penurunan kualitas lingkungan (Putranto, 2015).

Permasalahan umum yang dirasakan sebagian besar negara di dunia adanya kerentanan lingkungan dari akibat perubahan iklim global yang salah satunya wilayah zona pesisir (Michel dan Pandya, 2010). Dalam penentuan tipologi di wilayah pesisir dapat membantu dalam penelitian tentang masalah spasial yang khususnya di kawasan pesisir, perlu diperhatikan antara lain; lingkungan abiotik, keadaan geomorfologi, bentuk tutupan lahan yang mendominasi, penggunaan lahan, interaksi kegiatan manusia di darat yang mempengaruhi proses di laut dan sebaliknya aktivitas laut yang masih mempengaruhi proses kegiatan manusia di daratan (Kiousopoulos, 2008). Beberapa bentuk fisik di pesisir yang menjadi pengendali dari adanya erosi pantai, badai maupun banjir diantaranya; berbagai terumbu karang, ekosistem hutan mangrove, estuari, padang lamun maupun pasar pantai yang sekaligus ikut serta mengurangi risiko polusi dari daratan sekaligus faktor antropoghenik (Rudianto, 2014). Kabupaten Tulungagung masih termasuk kawasan perbukitan karst yang banyak dijumpai di wilayah pesisirnya. Kawasan karst di wilayah Tulungagung ini berdasarkan fisiografis Pulau Jawa pendapat Van Bemmelen (1949) termasuk dalam zona pegunungan selatan Jawa Timur bagian tengah dengan kisaran tertinggi 150 meter dan terendah 25 meter (Kusumayudha, 2005).

Pengelolaan pesisir di Tulungagung tentunya dapat memberikan manfaat masyarakat kawasan pesisir dan pada pemerintah setempat, maka sangat penting untuk diketahui tentang kajian tipologi pesisir dan dinamika perkembangannya. Sehingga kawasan pesisir berperan besar memberikan manfaat akan tetapi membutuhkan pengelolaan yang baik serta diperlukan kegiatan melestarikan sumber daya yang ada di pesisir (Hamuna dkk, 2018).

Pemanfaatan pesisir Tulungagung dikembangkan berbagai kegiatan seperti kegiatan pengembangan pariwisata, kegiatan nelayan, kegiatan pertanian. Berdasarkan fenomena tersebut dapat sebagai acuan identifikasi kerentanan pantai secara spasial dan dapat memprediksi kemungkinan perubahan masa mendatang. Selanjutunya hasil identifikasi untuk mengetahui berbagai kemungkinan yang muncul sebagai potensi bencana di pesisir Tulungagung. Sehingga dapat sebagai acuan dalam menentukan pembangunan di wilayah pesisir untuk menimalisir risiko bencana. Oleh karena itu diperlukan strategi pengelolaan wilayah pesisir secara terpadu untuk tujuan keberlanjutan dan mengintegrasikan berbagai disiplin ilmu diantaranya tentang kajian tipologi, dinamika dan potensi bencana alam di kawasan pesisir Kabupaten Tulungagung.

Penelitian ini bertujuan untuk mengetahui tipologi-tipologi, dinamika dan 
potensi bencana yang berkembang di kawasan pesisir Kabupaten Tulungagung.

\section{BAHAN DAN METODE}

Penelitian ini merupakan penelitian deskriptif kualitatif, dengan menggunakan metode pengamatan, dokumentasi, inventarisasi secara cepat (rapid survei) dan penentuan tipologi kawasan pesisir Tulungagung menggunakan klasifikasi tipologi pesisir menurut Shepard (1972) dalam Pethik (1984) yang pertama Pesisir Primer (primary coast), merupakan pesisir yang bentukannya besar dipengaruhi oleh proses dari daratan. Selanjutnya pesisir primer masih diklasifikasikan, (a) tipology land erosion coast, merupakan pesisir yang bentuk dan perkembangannya dipengaruhi oleh erosi pada lahan bawah daratan serta dipengaruhi oleh terjadinya inundasi dari laut. Proses yang dominan adalah adanya erosi. Proses ini membentuk pantai telukteluk dan garis pantai berbeda-beda. (2) tipologi volcanis coast, merupakan tipe pesisir yang terbentuk sebagai akibat proses gunungapi, berupa pesisir yang ada aliran lava, ada batuan beku maupun materialmaterial piroklastis yang diakibatkan pada saat erupsi dan meletusnya gunung api. (3) tipology structurally shaped coast, merupakan pesisir yang diakibatkan oleh adanya patahan/pelipatan yang dicirikan adanya bentuk-bentuk abrasi pada dinding cliff-nya. (4) tipology sub aerial deposition coast, merupakan tipe pesisir yang bentuknya dipengaruhi oleh materialmaterial daratan seperti sedimen sungai, terjadinya glasial, fkator angin, atau adanya longsong tebing ke arah laut.

Sedangkan pesisir sekunder (secondary coast), merupakan pesisir yang terbentuk karena proses-proses dari laut. Dalam pesisir sekunder ini ada tiga tipe pesisir, pertama marine deposition coast yang merupakan pesisir yang dibentuk oleh proses deposisi material atau adanya sedimentasi laut yang termasuk jenisnya ada barrier beaches dan barrier spits. Kedua tipe pesisir Wave Erosion Coast yang merupakan pesisir dengan adanya aktivitas gelombang besar dapat mempengaruhi bentuk garis pantai baik lurus atau garis pantainya yang tidak teratur. Ketiga tipe pesisir Coast Built by Organism yang merupakan pesisir bentukannya dipengaruhi oleh aktivitas hewan maupun tumbuhan (Marfai, dkk, 2013). Setiap kawasan pesisir memiliki karakteristik yang khas sebagai tipologi pesisirnya, sehingga akan membedakannya dalam pemanfaatan lahan serta perubahan perkembangannya.

\section{Penentuan Dinamika Kawasan Pesisir Kabupaten Tulungagung}

Dinamika di kawasan pesisir merupakan suatu perubahan yang terjadi pada ruang maupun waktu tertentu yang disebabkan oleh faktor tenaga dari dalam bum (endogen) dan tenaga dari luar bumi (eksogen) termasuk dalam hal ini faktor kegiatan manusia. Pemanfaatan sumberdaya di kawasan pesisir untuk memenuhi kebutuhan manusia seperti pariwisata, industri, pembangunan permukiman turut ikut serta sebagai faktor yang menimbulkan kerusakan lingkungan, serta menjadi pengaruh timbulnya konflik sosial antar sektor dan hal ini berdampak pada terhambatnya kegiatan pelestarian lingkungan (Rosytha, 2016).

Pelaksanaan pengelolaan pesisir dapat melalui pendekatan yang pertama pengelolaan yang berbasis pada partisipasi masyarakat setempat dan yang kedua dapat dilakukan pengelolaan secara kolaboratif dengan mengelola kawasan pesisir fokus utamanya masyarakat lokal dan menjalin kerjasama dengan pihak terkait atau pemerintah sebagi pemangku kepentingan (Siry, 2011). Sehingga dinamika di kawasan pesisir tidak hanya dipengaruhi oleh faktor alam baik dari darat maupun dari laut tetapi disebabkan banyaknya kegiatan manusia seperti reklamasi pantai, kegiatan pertanian, pembangunan pelabuhan, pemukiman di pesisir, yang akan menjadi tipologi buatan manusia. 


\section{Penentuan Potensi Bencana Kawasan Pesisir Tulungagung}

Bencana merupakan suatu peristiwa yang terjadi dapat mengancam maupun merusak keseimbangan kehidupan masyarakat maupun hewan, tumbukan yang disebabkan gejala alam atau non alam seperti manusia sendiri sehingga timbulnya kerugian lingkungan, korban jiwa, harta benda hilang dan dapat terhadap keadaan psikologis seseorang yang terdampak (UU No. 24 Tahun 2007). Salah satu bencana yang terjadi secara umum di wilayah pesisir saat ini adanya perubahan iklim yang dapat berdampak pada kehidupan masyarakat kawasan pesisir khususnya masyarakat yang bermata pencaharian sebagai nelayan (Ulfa, 2018). Maka bencana di pesisir maupun laut dari terjadinya perubahan iklim ini mengakibatkan berbagai kerusakan lingkungan fisik dan lingkungan ekonomi, sosial masyarakat di zona pesisir (Fang. dkk, 2018).

Berbagai masalah bencana di kawasan pesisir di seluruh dunia sejak delapan tahun terakhir seperti; erosi pantai mempengaruhi $70 \%$ pantai berpasir yang presentasinya terus meningkat, faktor penggunaan lahan yang berakibat terhadap sedimentasi di laut meningkat, pembangunan pelabuhan yang mempengaruhi arus air laut yang mengakibatkan terjadinya erosi di sekitar kawasan pelabuhan, dan kenaikan muka air laut (Bartolini. dkk, 2018).

Dalam perencanaan pembangunan di wilayah pesisir diharapkan tidak hanya memanfaatkan sumberdaya secara maksimal namun dapat melakukan perencanaan tata ruang yang berbasis mitigasi bencana. Pengaturan tata ruang yang berbasis bencana termuat dalam Undang-Undang No. 26 Tahun 2007, dengan ini merupakan bentuk upaya untuk mengurangi dampak bencana dan meningkatkan keselamatan manusia dan penghidupannya di kawasan pesisir (Taslim. dkk, 2017). Sehingga pentingnya dalam mengetahui potensi bencana di kawasan pesisir Tulungagung ini sebagai pendukung dalam perencanaan pengembangan wilayah pesisir berbasis mitigasi bencana untuk pembangunan yang berkelanjutan.

\section{HASIL DAN PEMBAHASAN \\ Tipologi Pesisir di Kawasan Pesisir Kabupaten Tulungagung}

Berbagai tipologi kepesisiran yang ada di kawasan pesisir Tulungagung dipengaruhi proses geologi dan sampai saat ini prosesnya juga dipengaruhi oleh pasang surut air laut, sungai maupun kegiatan pemanfaatan lahan oleh manusia yang bermukim di pesisir. Secara geologi, kawasan bagian selatan Tulungagung termasuk bagian kawasan rangkaian perbukitan kapur atau perbukitan karst. Hal ini beberapa sebagian pesisirnya berupa cliff atau tebing-tebing akibat dari proses pengangkatan. Hal ini yang menjadi bagian plato selatan pulau jawa bagian selatan yang terjadi pengangkatan dan beberapa sebagian dibuktikan bentuknya yang miring ke selatan (Tjian dan Samodra, 2011; Fadilestari,dkk 2011; Nusantara, 2011). Selanjutnya ada tipologi yang dipengaruhi oleh gelombang air laut atau wave erosion coast. Berbagai kajian tipologi di beberapa lokasi kajian penelitian sebagai berikut.

Tipologi land erosion coast, ditemukan di Pantai Molang sekaligus memiliki proses yang lain yaitu adanya wave erosion coast seperti pada Gambar 1 berikut.

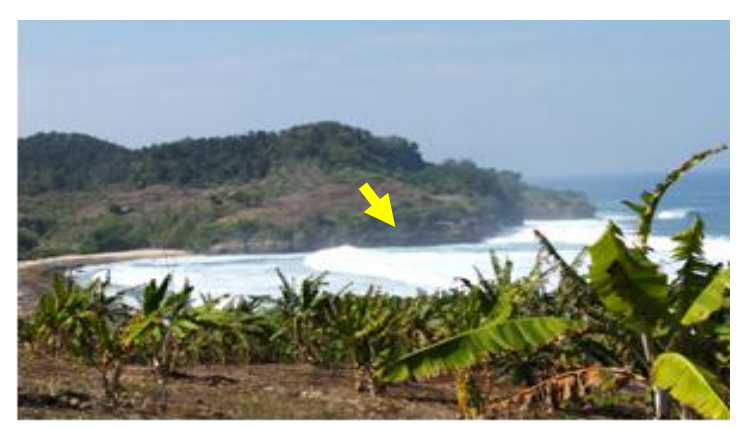

Gambar 1. Land erosion coast (Sumber: Putranto, 2019)

Pada Gambar 1, arah panah menunjukkan Land erosion coast di Pantai Molang yang dibuktikan dengan adanya erosi pada lahan bawah daratan yang 
terjadinya dipengaruhi oleh inundasi dari laut. Pada Pantai Molang ini arus gelombangnya tinggi, sehingga terjadi erosierosi pada dinding perbukitan pantai. Selanjutnya hasil proses gelombang air laut yang mengikis batuan kapur menghasilkan sedimentasi berupa pasir pantai yang merupakan tipologi marine deposition coast. Pantai molang mengalami perkembangan akibat adanya proses yang terus menerus gelombang air laut mengerosi dinding-dinding batuan perbukitan struktural batuan karts. Hasil inundasi yang diendapkan pada kawasan pantai berupa pasir putih. Selain itu, ada proses erosi rataan terumbu karang yang terlihat pada gambar tersebut ketika air laut sedang mengalami surut, sedangkan proses Structurally Shaped Coast dapat dilihat pada Gambar 2 berikut.

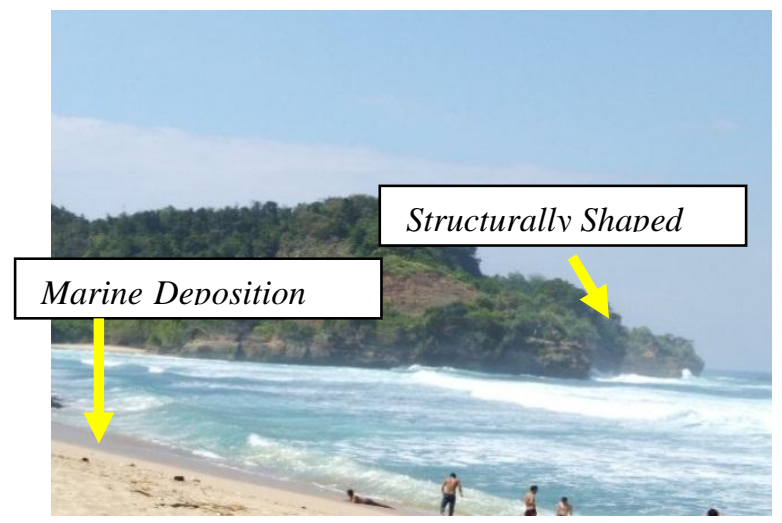

Gambar 2 . Tipologi Structurally Shaped Coast dan Tipologi Marine Deposition Coast (Sumber: Putranto, 2019)

Gambar 2 merupakan bagian sisi timur Pantai Molang, pada arah panah berwarna kuning sebelah kanan menunjukan pantai dengan tipologi structurally shaped coast hasil pengangkatan yang ditandai tebingtebing yang curam dan perkembangan pada tebingnya mengalami reruntuhan. Dengan adanya reruntuhan pada dinding cliff dan berkembang tipologi wave erosion coast. Selanjutnya, pesisir ini memiliki tipologi marine deposition coast sebagai hasil sedimentasi atas erosi-erosi pada tebing oleh gelombang air laut.

\section{Dinamika Kawasan Pesisir di Kabupaten Tulungagung}

Dinamika di kawasan pesisir merupakan suatu perubahan yang terjadi pada ruang maupun waktu tertentu yang disebabkan oleh faktor tenaga dari dalam bumi (Endogen) dan tenaga dari luar bumi (eksogen) termasuk dalam hal ini faktor kegiatan manusia. Berbagai kegiatan manusia berkembang di kawasan pesisir, baik untuk kegiatan pertanian pemukiman atau untuk pengembangan rekreasi. Sedangan untuk salah satu perkembangan pemanfaatan di kawasan pesisir Tulungagung yang tidak berkembang sebagai tempat nelayan dan pemukiman, dimanfaatkan untuk kegiatan tambak udang seperti Gambar 3 berikut.

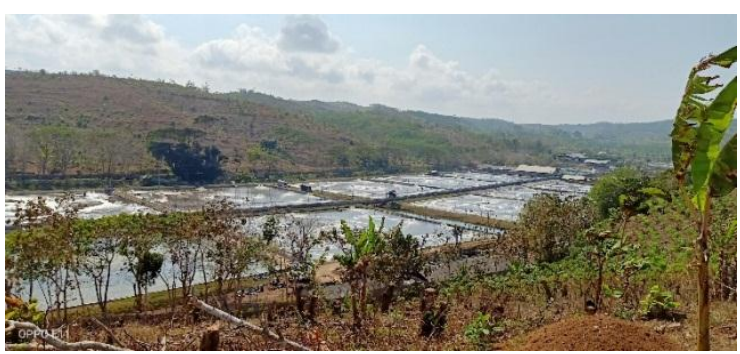

Gambar 3. Pemanfaatan Kawasan Pesisir untuk Pertanian Tambak Udang

Gambar 3 menunjukkan bentuk dinamika yang berkembang yaitu kegiatan pengelolaan pesisir dalam sektor industri untuk mengoptimalkan potensi sumberdaya pesisir. Di pantai Molang terdapat kegiatan pertanian, dan industri tambak udang. Sehingga dinamika di kawasan pesisir Molang tidak hanya dipengaruhi oleh faktor alam tetapi juga dipengaruhi oleh manusia. Selanjutnya dinamika yang berkembang di Pantai Sine ini berkembang pemukiman penduduk yang sebagian besar bermata pencaharian sebagai nelayan dan kegiatann pengembangan sektor pariwisata. Masyarakat yang ikut serta pada kegiatan pariwisata banyak berusaha pada bidang kuliner atau warung makan, penyewaan motor pantai ATV dan sebagainya, seperti pada Gambar 4. 


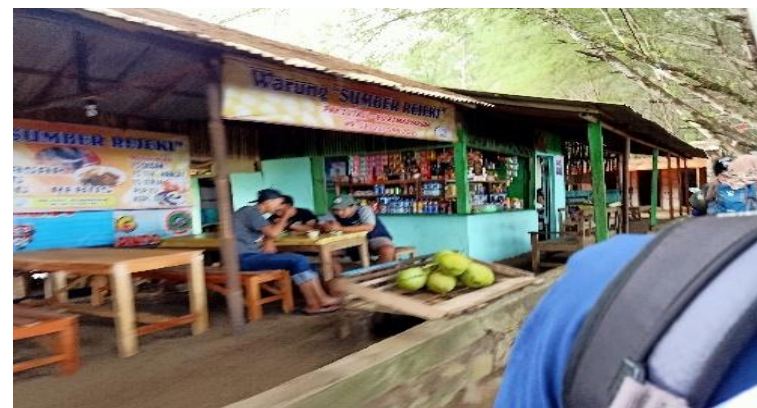

Gambar 4. Warung Makan di Sekitar Pantai Sine

Pada Gambar 4 menunjukkan suasana di kawasan area tanaman cemara udang yang sebagian lahan sudah dimanfaatkan untuk memenuhi kebutuhan wisatawan. Warung makan yang tertata rapi ini akan memberikan nilai yang baik untuk penataan di kawasan objek wisata. Namun disisi lain karena permintaan lahan tidak selalu terpenuhi, maka sering munculnya masyarakat yang menyalahi aturan dalam memanfaatkan lahan yang tidak sesuai dengan peruntukannya. Berikut ini contoh pemanfaatan lahan yang tidak sesuai dengan peruntukkan sempadan sungai.

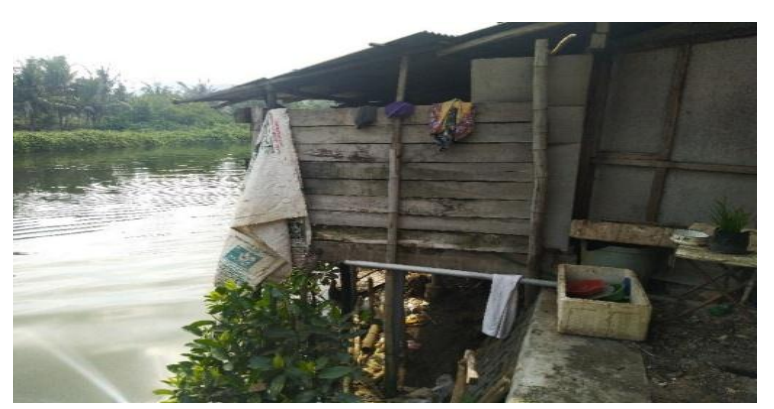

Gambar 5. Sempadan Sungai yang Mengalami Perubahan Fungsi

Berdasarkan Gambar 5, dapat diasumsikan adanya kekurangan lahan untuk pembangunan warung yang akhirnya mendidirikan warung di atas sungai. Keadaan tersebut secara jelas menyalahi aturan fungsinya. Bahwa sempadan sungai seharusnya tidak ada pendirian bangunan baik untuk kegiatan pemukiman maupun untuk usaha warung makan.

Sebagaimana pemanfaatan lain yang baik dapat dilihat pada Gambar 6 sebagai berikut:

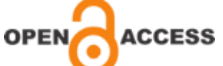

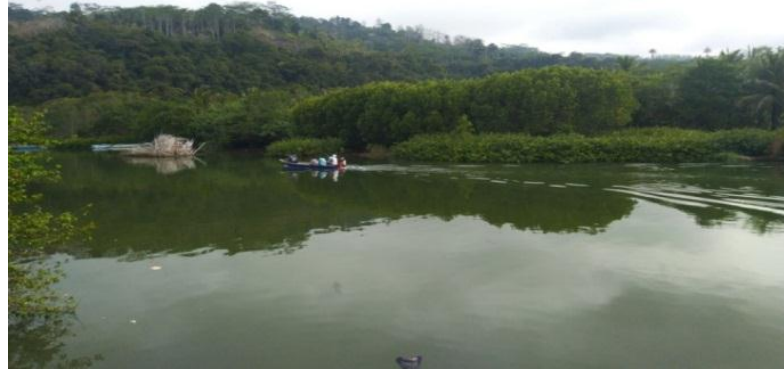

Gambar 6. Potensi Wisata Sungai

Gambar 6 merupakan laguna di Pantai Sine berasal dari aliran sungai di Pantai Sine sisi barat, kemudian mengalir menuju laut. Potensi sungai sisi barat yang ada di kawasan Pantai Sine dimanfaatkan untuk kegiatan jasa lingkungan. Kegiatan jasa yang ditawarkan masyarakat adalah pariwisata susur hutan mangrove dengan kapal motor. Pemanfaatan sumberdaya pesisir untuk memenuhi kebutuhan manusia memang membutuhkan pengelolaan yang tepat agar tidak menimbulkan kerusakan lingkungan.

Selain sebagai pelabuhan pantai Popoh juga memiliki daya tarik berupa keindahan pemandangan teluknya. Hal ini menjadi daya tarik wisatawan untuk berkunjung ke pantai Popoh untuk sekedar jalan-jalan atau menikmati keindahan panorama yang disuguhkan di pantai Popoh. Dinamika yang lain yaitu pemanfaatan potensi pesisir berupa terowongan sungai ini turut memenuhi kebutuhan masyarakat sekitar pesisir dalam kebutuhan listrik, selain itu juga dapat menyerap tenaga kerja.

\section{Potensi Bencana di Kawasan Pesisir Kabupaten Tulungagung}

Bencana di pesisir merupakan suatu peristiwa alam yang dapat disebabkan oleh adanya dampak aktivitas kegiatan manusia, karena menyebabkan perubahan kondisi lingkungan fisik di kawasan pesisir baik yang mempengaruhi ekosistem lingkungan maupun yang berdampak terhadap adanya korban jiwa, kepemilikan harta benda (Undang-Undang No 27 Tahun 2007). Berdasarkan tipologi dan dinamika yang ada di pesisir Molang maka potensi bencana 
apabila terjadi yaitu gelombang besar atau gelombang tinggi dapat berdampak pada kegiatan tambak udang yang dikembangkan di kawasan pesisir tersebut.

Mengacu pada United NationsInternational Strategy for Disaster Reduction (ISDR, 2002) bahwa ancaman di kawasan pesisir dapat dibedakan, yaitu ancaman secara alamiah (hidrometerologi, geologi, dan biologi) dan ancaman yang dikarenakan adanya kegiatan manusia yang mempengaruhi kondisi lingkungan sekitarnya (kerusakan lingkungan dan ancaman teknologi).

Jika mengacu terhadap UndangUndang No 27 Tahun 2007 mengenai sempadan pantai masih dapat dilakukan kegiatan pemanfaatan potensi sumberdaya yang ada di kawasan pesisir. Namun sebaiknya dalam pemanfaatan sumberdaya yang ada tetap mengacu pada aturan yang ada serta memperhatikan kondisi lingkungan untuk mengurangi dampak bencana di kawasan pesisir seperti gelombang besar. Pembuatan tambak udang yang ada di kawasan pesisir pantai Molang yang tidak memperhatikan sempadan pantai, dapat mengakibatkan terjadinya degradasi lingkungan akibat campur tangan kegiatan manusia yang dilakukan di kawasan pesisir (Triatmojo, 1999). Sehingga di kawasan pantai Molang memiliki kerentanan bencana alam pesisir yang rendah. Hal ini karena di kawasan pesisir tersebut tidak berkembang sebagai permukiman penduduk atau tempat tinggal dan kegiatan pariwisata belum berkembang sehingga aktivitas kegiatan manusia masih sedikit. Pesisir Pantai Dlodo yang memiliki muara sungai dapat mempengaruhi dinamika di Pantai Dlodo seperti pada Gambar 7.

Berdasarkan Gambar 7 menunjukkan bahwa dengan adanya sungai tersebut jika terjadi gelombang tinggi lebih cepat luasan gelombang mengarah ke pesisir karena melewati aliran sungai. Pemukiman yang jauh dari pantai tetapi tidak jauh dari sungai akan memiliki risiko tinggi akibat luapan sungai. Bentuk pantai yang sebagian besar datar dan dikelilingi perbukitan juga perlu waspada bagi masyarakat yang bertempat dalam kawasan tersebut. Berdasarkan keadaan tipologi kepesisiran Pantai Dlodo memiliki wilayah datar yang luas dan berbukit serta pemanfaatan lahan untuk permukiman penduduk berada di perbukitan, maka lokasi pesisir Pantai Dlodo dapat dikategorikan memiliki potensi bencana alam pesisir yang rendah karena secara umum permukiman penduduknya berada di atas perbukitan dengan ketinggan 1-8 meter Dpal.

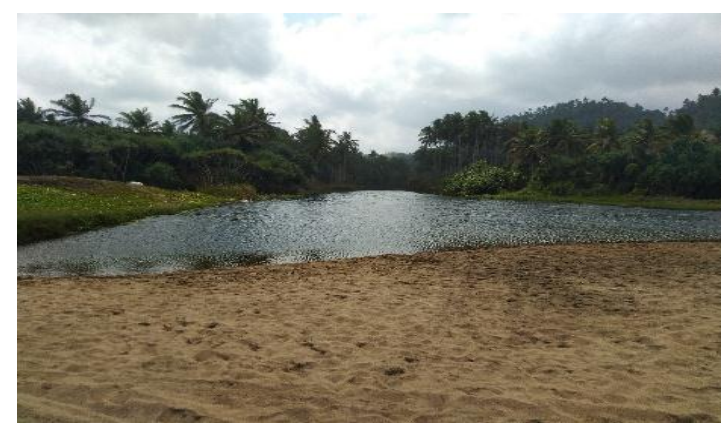

Gambar 7. Sungai di Pantai Dlodo

Pesisir Pantai Sine dengan perkembangan pemukiman yang pesat di kawasan pesisir yang landai dan tipe pantainya berteluk yang dikelilingi perbukitan memiliki tingkat resiko bencana yang tinggi apabila terjadi gelombang tinggi seperti Tsunami. Hal tersebut tentunya faktor topografi dan teluk yang sempit ini akan menjadi titik volume air laut yang tidak bisa menyebar dibandingkan daerah pesisir lain yang pantainya tidak berbentuk teluk. Kawasan pesisir yang memiliki dinamika perkembangan yang cepat, dalam pemanfaatan air tanah juga sangat harus diperhatikan, mudahnya kawasan pesisir yang air tanahnya mengalami intrusi air laut karena faktor penggunaan air tanah yang tidak memperhatikan ketersediaan lingkungan dan pemanfaatan oleh manusia yang tinggal di kawasan pesisir tersebut.

Berdasarkan kondisi bentuk pantai Sine yang berupa teluk, dan wilayahnya datar serta perkembangan pemukiman padat banyak yang menyalahi sempadan pantai, maka kawasan pesisir Pantai Sine ini memiliki kerentanan tinggi terhadap 
bencana alam di kawasan pesisir seperti gelombang tinggi maupun bencana Tsunami akibat gempa bumi. Bencana lingkungan kumuh karena selain sebagai pemukiman yang padat, kawasan ini juga berkembang sebagai tempat pelelangan ikan serta kegiatan pariwisata.

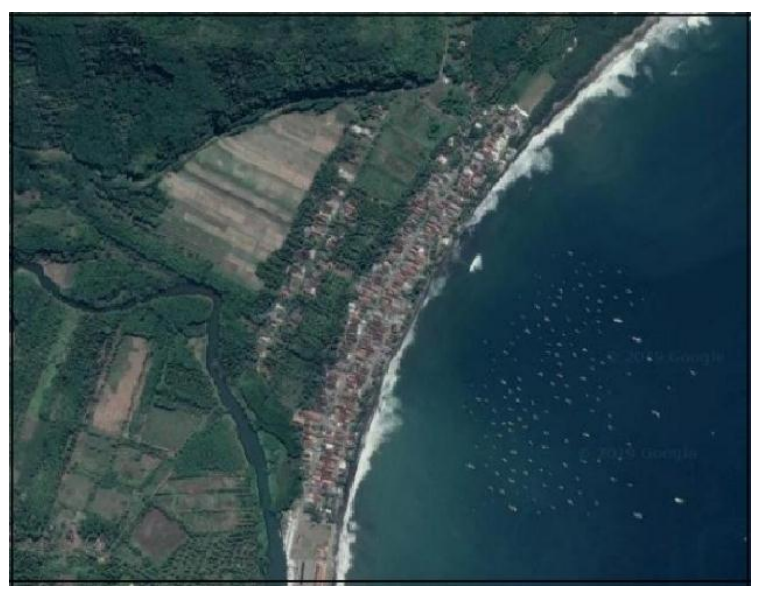

Gambar 8. Citra Satelit Pantai Sine

Berdasarkan Gambar 8, menunjukkan bahwa kawasan pesisir pantai sebagai besar perkembangan permukiman berada dekat dengan bibir pantai. Permukiman yang padat ini memiliki kerentanan karena kepadatan bangunan yang tinggi dapat mempersulit proses evakuasi jika terjadi gelombang besar ataupun gempa bumi dan banyak bangunan ini mengindikasikan semakin banyak jumlah penduduk yang harus dievakuasi. Pemukiman yang padat dengan jumlah penduduk yang banyak tentunya memiliki kebutuhan besar terhadap air tanah untuk memenuhi kebutuhan sehari-hari.

Pengambilan air tanah di kawasan pesisir yang tinggi tanpa memperhatikan konservasinya dapat berdampak terhadap pengurangan ketersediaan air tanah serta dapat mempercepat aliran air laut masuk ke tanah wilayah pesisir sehingga memicu terjadinya intrusi air laut. Mitigasi dapat dilakukan dengan membuat profil wilayah sebagai dasar untuk menyusun rencana aksi mitigasi bencana seperti bencana gempa bumi, gelombang musiman, maupun gelombang tinggi tsunami sebagai bencana susulan dari gempa bumi. Sebagaimana yang disebutkan oleh Triatmaja (2010) bahwa kegiatan mitigasi dapat dilakukan dengan dua pendekatan, yaitu pendekatan fisik dan pendekatan non fisik.

\section{KESIMPULAN DAN SARAN}

Secara umum tipologi pesisir di Tulungagung berbentuk structurally shaped coast, berkembang tipologi wave erosion coast dan sub-aerial deposition coast. Bentuk pantainya didominasi bentuk teluk dan sebagian berupa cliff atau tebing-tebing tinggi. Tipologi lain berkembang adanya pemanfaatan sumber daya alam yang dikelola oleh masyarakat.

Perkembangan dinamika kepesisiran lebih dipengaruhi oleh faktor alamiah seperti faktor geografi, gelombang air laut, sungai maupun faktor kegiatan manusia. Kegiatan manusia seperti pemanfaatan lahan pesisir untuk kegiatan permukiman, pengembangan tambak, pengembangan wisata serta pembangunan sarana dan prasarana objek pariwisata. Sedangkan potensi bencana alam yang ada di kawasan pesisir secara umum sama memiliki kerentanan akibat perubahan iklim secara global, akan tetapi memiliki tingkat risiko yang berbeda berdasarkan bentuk morfologi pantai, jumlah padatnya bangunan pemukiman maupun jumlah manusia yang mendiami. potensi bencana tidak hanya gelombang tinggi saja, tetapi dapat berupa abrasi, intrusi air laut. Setiap wilayah memiliki kebutuhan komponen perencanaan pengurangan risiko bencana yang berbeda. Data informasi tipologi, dinamika dan potensi bencana di pesisir Tulungagung dapat sebagai acuan perencanaan pengelolaan dan pemanfaatan sumber daya di kawasan pesisir untuk pengurangan risiko bencana alam kepesisiran, memberikan pengetahuan kepada masyarakat setempat, sebagai dasar penyusunan kebijakan tata ruang zonasi wilayah pesisir.

\section{DAFTAR PUSTAKA}

Bartolini S, dkk. (2018) Augmented Virtuality for Coastal Management: A Holistic Use of In Situ and Remote 
Sensing for Large Scale Definition of

Coastal Dynamics. International Journal of Geo-Information. 2018, 7, 92.

Departemen Kehutanan. (1992). Koservasi Sumber Daya Alam Hayati dan Ekosistemnya. Biro Hubungan Masyarakat Sekretariat Jenderal Departemen Kehutanan. Jakarta.

Fadilestari, I. Novian, M.I. dan Husein, S. (2011). Diagenetic Changes on Secondary Porosity in Reservoir Potential of Wonosari Limestones, Panggang, Gunungkidul Yogyakarta. Makalah dalam Asian TransDisciplinary Karst Conference, 7-10 Januari 2011. Fakultas Geografi Universitas Gadjah Mada, Yogyakarta.

Fang J, Liu W, Yang S, Brown S, Nicholls RJ, Hinkel J, Shi X, Shi P. (2017) Spatial-temporal changes of coastal and marine disasters risks and impacts in Mainland China. Jurnal Elseiver Ocean \& Coastal Management 139.

Hamuna B, Sari A. N, Alianto. (2018). Kajian Kerentanan Wilayah Pesisir Ditinjau dari Geomorfologi dan Elevasi Pesisir Kota dan Kabupaten Jayapura, Provinsi Papua. Jurnal Wilayah Dan Lingkungan. 6 (1): 1-14.

ISDR. (2002). Living with Risk: A Global Review of Disaster Reduction Initiative. ISDR: Geneva.

Kiousopoulos J. (2008) Methodological approach of coastal areas concerning typology and spatial indicators, in the context of integrated management and environmental assessment. Jurnal Springer Science.

Kusumayudha, S.B. (2005). Hidrogeologi Karst dan Geometri Fraktal di Daerah Gunungsewu. Yogyakarta: Adi Cita.

Marfai MA, Cahyadi A, Anggraini DF. (2013) Tipologi, Dinamika, Dan Potensi Bencana Di Pesisir Kawasan Karst Kabupaten Gunungkidul. Forum Geografi. 27(2): 147 - 15.

Michel dan Pandya (2010) dalam Carola Betzold, dkk. Seawalls as a response to coastal erosion and flooding: a case study from Grande Comore, Comoros (West Indian Ocean). Jurnal SpringerVerlag Berlin Heidelberg. 13 August 2016.

Nusantara, V.D.M.; Novian, M.I. dan Husein, S. (2011). Facies and Depositional Environment of Wonosari Formation, Eastern Part of The Soutern Mountain, Pacitan, As A Response to Sea Level Change. Makalah dalam Asian TransDisciplinary Karst Conference, 7-10 Januari 2011. Fakultas Geografi Universitas Gadjah Mada, Yogyakarta.

Pethick, J. (1984). An Introduction to Coastal Geomorphology. London: Edward Arnold Ltd.

Putranto A. (2015). Analisis Potensi dan Perkembangan Pariwisata Bahari : Pengaruhnya Terhadap Kondisi Sosial Ekonomi Masyarakat Pulau Pari, Kepulauan Seribu, DKI Jakarta. Tesis. Universitas Gadjah Mada. Yogyakarta.

Rosytha A. (2016) Studi Dampak Pengembangan Pemukiman di Wilayah Pesisir Surabaya Timur. Jurnal Agregat (1).

Rudianto. (2014) . Research Journal Of Life Science. 1(1).

Siry. (2011). Desentralisasi dan pengelolaan wilayah pesisir di indonesia studi pada desa kohod kecamatan pakuhaji kabupaten tangerang. Jurnal Kawistara. 7(3): 207-314.

Taslim I, dkk. (2017). Studi Geomorfologi Kebencanaan Berbasis Analisis Spasial Untuk Pembangunan Berkelanjutan. Jurnal MIPA Tadulako. 7(2).

Tjian, H.D., Samodra, H. (2011). Active Crustal Deformation at The Coast of Gunungsewu, Jawa. Makalah dalam Asian Trans-Disciplinary Karst Conference, 7-10 Januari 2011. Fakultas Geografi Universitas Gadjah Mada, Yogyakarta. 
Triatmadja, R., (2010). Tsunami, Kejadian, Penjalaran, Daya Rusak, dan Mitigasinya. Gadjah Mada University Press: Yogyakarta.

Triatmodjo, B. (1999). Teknik Pantai. Yogyakarta: Beta Offset.

Ulfa M. (2018). Persepsi Masyarakat Nelayan Dalam Menghadapi Perubahan Iklim (Ditinjau Dalam Aspek Sosial Ekonomi). Jurnal Pendidikan Geografi: Kajian, Teori, dan Praktik dalam Bidang Pendidikan dan Ilmu Geografi. 23(1): 41-49.

Undang-Undang (UU) Republik Indonesia (2007) Nomor 24 Tentang Penanggulangan Bencana.

Van Bemmelen, R.W., (1949). The Geology of Indonesia, Vol. IA: General Geology of Indonesia and Adjacent Archipelagoes, The Hague, Martinus Nijhoff, vol. 1A, Netherlands. 